\title{
Does Teacher Licensure Matter? Basic Education Reform in the Philippine Education System
}

\author{
Alexander S. Acosta ${ }^{1}$ \& Imee C. Acosta ${ }^{2, *}$ \\ ${ }^{1}$ Administration Department, Philippine School Doha, Al Messila Area, Doha, Qatar \\ ${ }^{2}$ Fashion \& Graphic Department, Virginia Commonwealth University in Qatar, Al Luqta Street, \\ Education City, Doha, Qatar \\ *Correspondence: Fashion \& Graphic Department, Virginia Commonwealth University in \\ Qatar, P.O. Box 8095, Al Luqta Street, Education City, Doha, Qatar. Tel: 974-5515-3642. \\ E-mail: icacosta@vcu.edu
}

Received: November 2, 2016 Accepted: November 25, 2016 Published: December 3, 2016

doi:10.5296/ije.v8i4.10247ＵRL: http://dx.doi.org/10.5296/ije.v8i4.10247

\begin{abstract}
The Philippine government is currently investing on education reform through the Enhanced Basic Education Program or the K-12 Curriculum. The recent basic education program does not only call for academic excellence but also on higher teacher qualification. The purpose of this study is to determine whether or not teacher licensure matters in the implementation of the basic education reform in the Philippine Education system. Qualitative in orientation, this study utilized Phenomenology as its research design to capture the lebenswelt of college teachers who are distraught by the implementation of the new K-12 curriculum. Data were gathered through interviews and the analysis of data was empirically observed using the following steps: transcribing, coding, theming, verifying, and analyzing. The analysis of data in this phenomenological inquiry yielded three essential themes based on the respondents' major statements pertaining to eligibility that makes the college teacher qualified to teach in the Senior High School of the new K-12 program, namely: full eligibility, provisionary eligibility, and temporary eligibility. The college teachers in this study accept and favor the Department of Education's teaching licensure requirement. They believe that passing the Licensure Examination for Teachers (LET) is an important requirement before entering the classroom. The shared experiences of the participants of the study serve as a primordial source to raise awareness about the value and importance of teacher licensure to meet the high quality standards set by the profession and the hiring standard recognized by the government and public schools as an assurance of competence and quality.
\end{abstract}

Keywords: Teacher Licensure, Teacher Certification, Eligibility, Teacher Standards 


\section{Introduction}

A professional teacher license or teacher certification is the highest mark of professional accomplishment that makes the teacher a member of a larger network of accomplished educators shaping the profession. It demonstrates the equivalent of a four-year education degree which shows that a teacher has met all standards required for the profession and would elevate the educator to a truly learned profession (National Board for Professional Teaching Standards, 2015). Licensure is an important element to assure quality in the teaching workforce. It establishes the floor intended to distinguish between those who have the desired level of competence to begin practice and those who do not. Many professions use licensing systems to select individuals into their fields and to prevent those considered incompetent from practicing. It is a measure of knowledge of basic skills, subject matter, and how to teach (Mitchell, 2001; ETS, 2004). In the Philippines, the Licensure Examination for Teachers (LET), formerly known as Philippine Board Examination for Teachers (PBET), of the Professional Regulation Commission (PRC), measures the extent of the knowledge acquired by teacher education graduates. Teacher licensure in the Philippines was promulgated and mandated by the Philippine Teachers Professionalization Act of 1994 which states that "All applicants for registration as professional teachers shall be required to undergo a written examination which shall be given at least once a year in such places and dates as the Board may determine upon approval by the Commission. Valid certificate of registration and a valid professional license from the Commission are required before any person is allowed to practice as a professional teacher in the Philippines, except as otherwise allowed under this Act.” (R.A. 7836, Art III Sec. 13 as cited in Aquino \& Balilla, 2015) Hence, this study argued that while R.A. 7836 mandates all teachers in the basic education to acquire license to teach, it is far more important that teaching craft of licensed teachers are recognized across the nation because they have met the highest standards set by the profession and not only for acquiring license for the sake of complying with its mandate (National Board for Professional Teaching Standards, 2015). In addition, one great benefit of licensure or teaching certification is job security. The teaching profession is more secure than many other fields, especially for certified or professionally licensed teachers (Professional Teaching Certification Advice, 2014).

The current basic education reform agenda in the Philippine basic education system recognized the professional teachers as partners in the implementation of the Enhanced Basic Education Act of 2013 or K-12, and as leaders in the promotion of quality teaching and learning; and teacher quality. Calderon's (2014) critique to the basic education reform was drawn from the current discourse, studies and loud views pertaining to the new K-12 program. The study concluded that if the goal is to improve the nation's student achievement then the real solution is improving the quality of teachers. This basic education reform agenda does not only call for academic excellence but also on higher teacher qualification. The K-12 Implementing Rules and Regulations stipulated that teachers who passed the Licensure Examination for Teachers are eligible to teach in the Senior High School and acquire a full time permanent position. While the graduates of science, mathematics, statistics, engineering, music and other degree courses needed to teach in their specialized subjects in elementary 
and secondary education with shortages in qualified applicants who have passed the Licensure Examination for Teachers (LET) are also allowed to teach, provided, that they pass the LET within five (5) years after their date of hiring. If such graduates are willing to teach in basic education on part-time basis, the provisions of LET shall no longer be required. The Department of Education (DepEd) and private educational institutions may hire practitioners, with expertise in the specialized learning areas offered by the enhanced basic education curriculum, to teach in the secondary level; provided, that they teach on part-time basis only. For this purpose, the DepEd, in coordination with the appropriate government agencies, shall determine the necessary qualification standards in hiring these experts (Official Gazette, 2013). The K-12 implementing rules and regulations has indicated that professional licensed teachers are more advantaged than those who are not since licensed college teachers who are displaced due to non-entry of freshmen students, hold a promising employment prospect because they are eligible to teach in the senior high school of the new K-12 program. The Department of Education (DepEd) needs 30,000 teachers for senior high school and its hiring policy grants full-time permanent teaching status to teacher applicants who passed the Licensure Examination for teachers (Commission on Higher Education, 2015). Hence, teacher licensure plays a critical role in securing readiness among college teachers to embrace the enhanced basic education curriculum and its anticipated impact.

However, the subject of faculty licensure generates a lot of discussion, both pro and con, particularly to the affected faculty of the K-12 implementation since the new program created a gap or a time when there are no students entering college. Those who graduated from high school have to proceed to take the mandatory senior high school program, the Grade 11 and 12, instead of going to college. This means that there are no college freshmen for SY 2016-2017 and SY 2017-2018; and there will be no second year enrollees for SY 2017-2018 and SY 2018-2019. Although there will already be college freshmen by 2018; yet, there will be no third year college students for SY 2018-2019 and SY 2019-2020, and no fourth year college enrollees for SY 2019-2020 and SY 2020-2021 (Lacamiento, 2014). Colleges and Universities or the Higher Education Institutions (HEIs) are expecting a drop in enrollment during these five years until SY 2021-2022 when things are expected to normalize (Geronimo, 2014). Therefore, no new enrollees would mean loss of income for colleges and universities, and possibly, not enough job for teachers, thus creating a serious threat to the employment of teachers working in the Higher Education Institutions (Malipot (2014). It was reported that a group of teachers from various colleges and universities expressed their fear that the employment of around 30,000 out of 90,000 college teachers nationwide may be affected starting 2016 (Casiple, 2014). This new Law that promises to produce employable Filipino high school graduates is however causing panic among presently employed administrators and teachers among colleges and universities (Geronimo, 2014).

In view of this, teacher licensure gives a promising prospect of continued employment during the transition period even if there will be college enrollment gaps since the teacher's professional license qualifies him/her to teach in the Senior High School (SHS) program of the K-12 and acquire a full-time permanent status. To remain employed, many licensed college teachers will probably apply to become high school teachers. On the other hand, 
non-holder of teaching license raises concern of displacement, retrenchment, and unemployment among those without a professional license. To address this gap, the Higher Education Institutions (HEIs) are working together with the Department of Education (DepEd) to cushion the impact of the K to 12 Program to college faculty members who are displaced due to the implementation of the Senior High School (SHS) Program. The affected college faculty can teach in the senior high school level with or without eligibility, but, the Department of Education (DepEd) allows non-licensed faculty to teach in the senior high school only on a temporary basis since there is an existing condition that requires them to pass the Licensure Examination for Teachers (LET) within five years. This provision is in placed to ensure that the enhanced basic education program meets the demand for quality teachers (Official Gazette, 2013). Licensure is the mark of a professional, it is an important requirement for any profession such as the law, medicine, or teaching. Most countries worldwide require teachers to pass the mandated licensure examination before they are considered "highly qualified" and eligible for employment as teachers, and be conferred the title of being a professional teacher. (Riney, Thomas, Williams, Kelley 2006; Aquino and Balilla, 2015). It is a standard recognized by employers and their clients, by governments and by the public as an assurance of dedication, skill and quality (Kent, 2015).

The basic education reform in the Philippine Education system has resulted to various issues and concerns among college teachers for possible displacement or loss of employment. This paper aims to determine and understand the value of teacher licensure especially in terms of whether or not the professional teacher license is an important consideration in education reform and in qualifying the teachers. The insights gained from this study would be of interest to teacher education students, teachers, and teacher education institutions in terms of continuous improvement of teacher education training, pedagogical instruction and the preparation for the Licensure Examination for Teachers. The shared experiences of the participants of the study may encourage the teacher education students and non-licensed teachers to exert more effort to be better prepared for the licensure examination. It is hoped that the contributions of this study may shed light to all teachers to believe that licensure examination is an important part of their professional development.

\section{Method}

\subsection{Study Design}

Qualitative in orientation, this study made use of phenomenological design to understand the lebenswelt or lived-world (Schwandt, 1997 as cited in Groenewald, 2004) of the college teachers who are affected by the basic education reform in the Philippine Education System. This design of inquiry, according to Creswell (2013), is coming from philosophy and psychology in which the researcher describes the lived experiences of individuals about a phenomenon as described by the participants. This description illuminates the specific, to identify phenomena through how they are perceived by the actors in a situation (Lester, 1999) and attempts to explicate the meaning structures developed through the experience of the person being questioned (Holroyd, 2001). Therefore, the operative word in phenomenological 
research is 'describe' in which the researcher describes as accurately as possible the phenomenon, refraining from any pre-given framework, but remaining true to the facts (Groenewald, 2004). This design has strong philosophical underpinnings and typically involves conducting interviews (Giorgi, 2009; Moustakas, 1994 as cited in Creswell, 2013).

\subsection{Research Participants}

The participants of this study consist of twelve college faculty members from different universities and colleges in the Philippines who were purposely chosen because of their direct experience and knowledge; and their relevance to the study that meet the researcher's intent to explain, describe, and interpret the phenomenon (Hardon, Hodgkin, and Fresle, 2004; Maxwell 2013, as cited in Guetterman, 2015). The researcher confidently believes that capturing the lived-experiences of the 12 participants somehow sufficed the needed data for this study because in phenomenology certain number of respondents like 2-10 are more than enough to indicate the effectiveness and trustworthiness of the data (Mason, 2010; Greonewald, 2004; Creswell, 1998; Morse, 1994). The participants are composed of 7 females and 5 males; among them, 9 are married, 3 are single and the age group ranges from 30-60 years old. Two have completed Doctoral Degree, seven have completed Master's Degree, and three hold a Bachelor's Degree. Five of them are teaching in the public higher education sector, two are teaching from a locally funded college, and five are teaching from private higher education institutions. As to courses taught, seven are teaching specialized or major subjects and five are teaching general education subjects. In terms of employment status, majority are holding a full-time permanent status, while two are part-timers or temporary. All of them hold a professional license except for one respondent. They have been teaching from 5-20 years except for one who has been teaching for more than 30 years.

\subsection{Data Collection}

To gather data and information needed in this research study, a semi-structured interview was used. Prior to the interview, a written permission was sent to the Deans of colleges and universities. When the endorsement was sought, it was forwarded to the heads of the departments who gave the go signal to schedule the interviews of the participants, then, the appointment of time and place for the interview was arranged.

Semi-structured interviews consist of several key questions that help to define the areas to be explored, but also allows the interviewer or interviewee to diverge in order to pursue an idea or response in more detail (Gill, Stewart, Treasure, Chadwick, 2008). It also allows participants the freedom to express their views in their own terms and can provide reliable, comparable qualitative data (Cohen and Crabtree, 2006). Information from interviews were recorded using audio tape and by making handwritten notes (Creswell, 2003; Sutton and Austin, 2015).

\subsection{Data Analysis}

Data gathered from the interviews were analyzed following the qualitative data analysis techniques. First, data is transcribed from the spoken word to the written word to facilitate analysis. Transcribed data were read through to get a feel of what is being said in order to 
surface the essence of the phenomenon. Once all data have been transcribed, re-read, and checked; it is now time to begin coding. Coding refers to identifying similarities and differences among a group of entities, segmenting, comparing, and labeling texts that are revealed through the participants' narratives as interpreted by the researcher. Then, data were juxtaposed, compared, and grouped into similar codes which is particularly useful to identify relationships between different themes. Themes are analyzed by reviewing the data within the themes until an understanding of each theme was reached. Then, a simulachrum is created to provide a visual model or representation of the findings of the study. To make the analysis more rigorous and increase the reliability of the method used and the validity of the interpretation; triangulation, member-checking or respondent validation, peer review or inter-rater reliability, and thorough analysis of the whole corpus of data were used (Lacey \& Luff, 2001; Ivankova \& Stick, 2007; Creswell \& Plano Clark, 2006; Leech \& Onwuegbuzie, 2007; Burnard, Gill, Stewart, Treasure, \& Chadwick, 2008; Sutton \& Austin, 2015).

\section{Findings}

Qualitative evidence through the articulations, musings, and verbalizations of the respondents in this phenomenological inquiry revealed three categories of eligibility, namely: full eligibility; is given to education graduates who are LET or board passers, provisionary eligibility; allows teachers to teach for 5 years without the license, and temporary eligibility; permits industry practitioners to teach on part-time basis. These classifications encompass the eligibility process in the Philippine Education System and license the teachers to teach in the public school's secondary level.

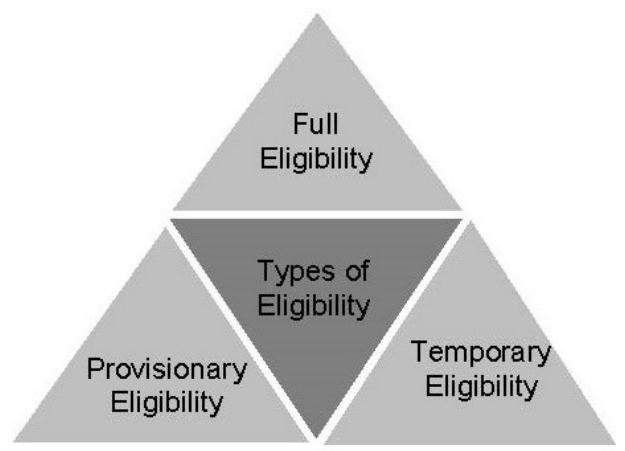

Figure 1. Types of Eligibility to Teach in K-12's Senior High School Program

\subsection{Full Eligibility}

Licensure examination is vital for all those who wish to become educators and be part of the roster of the professional teachers. This requirement allows graduates of the teaching profession to teach legally under the rule of law as required by the Department of Education. If one has acquired full eligibility, this opens the opportunity for him or her to teach in the public school. Confirmatory statements related to this are verbalized by the respondents:

"My advice for the would-be affected faculty is to let them take the Board Exam so 
that whenever the need arises, they can apply immediately, since DepEd will need more teachers during that time.” (R 9)

"For teachers 1, we advise them to pursue licensure examination so that they can be absorbed in DepEd's Senior High School program.” (R12)

With the start of Senior High School (SHS), the Department of Education (DepEd) has called on "qualified and highly-competent teachers, professionals, practitioners, and experts" interested in teaching subject areas of 4 SHS tracks: academic, technical-vocational-livelihood, arts and design, and sports (Geronimo, 2014). However, it has been stipulated that only applicants with a Professional Regulation Commission (PRC) teaching license "and/or appropriate certification" will be given permanent full-time status. This report is supported by the respondents, they said:

"The teachers are worried actually because there is a report that many teachers will be laid off with the full implementation of K-12. There will be very few teachers who will remain and it has been said that only the LET passers will keep their employment." (R10)

"The non-education part-timers are going to enroll in our College of Education to take the Teaching Certificate Program (TCP) as preparation for the K-12, and as soon as they can finish, they will be qualified to take the Licensure Examination for Teachers (LET). If they pass, they are qualified to teach in the DepEd." (R8)

Cognizant of this, full eligibity is not only a requirement imposed by DepEd or government schools, but some private institutions are also calling for licensed teachers to teach in their Senior High School program based on the shared account of the respondents from private universities and colleges. One of them mentioned:

"We will need to shift some of our teachers to Senior High School, but we also consider only those who are LET passers, tenured, and with good evaluation. MA qualification is only second. We are really considering the LET passers. If the teacher meets the qualifications and is willing to take the position, we will offer the job.” (R1)

This narrative is an unequivocal recognition of the significance of eligility or teaching license in qualifying the teachers. Eligibility makes the professor qualified to teach either in the public or in private educational institution and ready to teach in the Senior High School program, which is further supported below by one of the respondents:

"If I will rate the readiness of one of the departments in this college in terms of faculty, it's 10-10 because they are all board passers." (R1)

The preceding statements imply that teachers with full eligibility are education graduates who passed the Licensure Examination for Teachers (LET) and granted the professional national certification for teachers by the Philippine Regulatory Commission (PRC). In this context, this professional certification is referred to as full eligibility that offers teachers the complete qualification required for the teaching profession. They possess a valid license to practice 
teaching and qualified to teach full time in the Department of Education's senior high school program without any conditions.

\subsection{Provisionary Eligibility}

To some extent, teachers who are non-LET passers are given grace period to comply the Licensure Examination for Teachers (LET) as stipulated in the Implementing Rules and Regulations (IRR) of the "Enhanced Basic Education Act of 2013” (Republic Act No. 10533, Official Gazette, 2013). It allows non-LET passer teachers to teach in the SHS program, due to shortages of qualified applicants who have passed the Licensure Examinxation for Teachers (LET), provided, that they pass the LET within five (5) years after their date of hiring. Moreover, if such graduates are willing to teach in the basic education on part-time basis, the provisions of LET shall no longer be required. The shared verbalization of the respondent has confirmed as mentioned:

"In terms of faculty, we are preparing them for the transition to temporarily go to Senior High School, besides there is a moratorium that allowed them to teach in the secondary education for five years until they pass the board exam or get a license". (R12)

The impetus for granting the provisionary eligibility during the full implementation of the $\mathrm{K}-12$ program has been the surplus of teachers in the tertiary level and teacher shortage in the Senior High School level. This is also one of the measures to mitigate the negative impact of the $\mathrm{K}$ to 12 Program to the employment of faculty members who are working in the higher education sector. The interviewed participants spoke about it, and they said:

"We were told that when you are going to teach in the K-12, you are required to take and pass the LET. If you are not licensed, you are given five years to pass the board. So, I have to prepare and take units in education so I can take the LET. That's my personal preparation.” (R10)

"The part-timers who are education graduates but non-board passers, they can teach in the Senior High but they have to pass the Board Exam within 5 years so that they can obtain a permanent status." (R5)

\subsection{Temporary Eligibility}

With the enhanced basic education in place, DepEd and private schools also hire practitioners with expertise in the specialized learning areas offered by the K to 12 Program and graduates of technical-vocational courses with the necessary certification issued by the Technical Education and Skills Development Authority (TESDA) and underwent training administered by the Department of Educaiton (DepEd) or Higher Education Institutions (HEIs) as part-time teacher. One of the respondents attested to this hiring need under the K-12's Implementing Rules and Regulations (IRR).

"Since I am not an educator, personally, I am preparing. I took my NC II for massage therapy in Hospitality management because in our department, those 
faculty who are handling the major subjects should have the National Certificate." (R6)

Relative to this, temporary eligibility is granted to industry practitioners who are licensed in their respective field, and to those who are graduates of technical-vocational courses. In this context, these practitioners are non-education graduates and without Licensure Examination for Teachers (LET). They are encouraged to share their valuable knowledge and experience to the Senior High School students under the four track subjects. The respondents confirmed that their college or university is hiring practitioners.

"Mostly, our pat-timers are the senior superintendents, chief superintendents, and senior inspectors of the police department, who are specialized about police matters." (R2)

"The practitioners who are part-timers are a little nervous because they are really affected. Although, they will be accommodated later on to teach in the Senior High School. If they are teaching in the tertiary level, automatically, they can teach in the senior high even without the LET.” (R8)

Permitting the practitioners to teach in the SHS under the track subjects is one of the viable ways to ensure that students will successfully progress in their chosen track. However, a clear understanding by which the teachers should be certified for licensure is of paramount significance. In fact some of the part-time practitioners have taken measures in order to acquire the required qualification as mentioned by the respondent below.

"The other part-timers are willing to teach in the senior high school, that's why they have taken the Teaching Certificate Program (TCP) and enroll in the Bachelor of Secondary Education (BSED) and Bachelor of Elementary Education (BEED) programs and take the LET because they plan to apply in the DepEd.” (R9)

\section{Discussion}

Licensure examination is considered important by teacher education students in their professional development. It also gives them not only honour and prestige but a competitive advantage over those who are non-LET passers. (Aquino and Balillia, 2015). Considering the importance of eligibility to the teaching profession, passing the Licensure Examination for Teachers (LET) makes the educators professional teachers who are highly qualified, and eligible for employment as teachers both in private and public schools. The government, therefore, has a function to regulate the teaching practice by requiring aspiring teachers to pass the licensure examination before they engage in the teaching profession. The shared accounts and stories of the respondents are captured to strengthen the phenomenological claim of this study. Generated themes from the stories shared give a clear-cut picture of how eligibility or license-to-teach matters most in the Philippine education system. Each theme is discussed vividly to provide sufficient information related to K-12 program and its standard 
requirement. Thus, as Cordingley (2014) mentoined, a teacher licensing scheme could and should create an identity for the profession bigger than the sum of its parts.

\subsection{Full Eligibility}

A teaching license is a regulatory mechanism designed to shape the national teaching force since it plays an important role in determining teacher quality. Philippine Republic Act 7836, Section 2 reads, the State recognizes the vital role of teachers in nation-building and development through a responsible and literate citizenry. Towards this end, the State shall ensure and promote quality education by proper supervision and regulation of the licensure examination and professionalization of the practice of the teaching profession (Chan and Robles, 1994). Hence, teacher quality is regarded as a one of the key elements in educational policy. A study of Riney, Thomas, Williams, \& Kelly (2006) stated that most teacher education students accept licensure examinations as important requirements for any profession such as the law, medicine, or teaching. It is important to ensure that teachers are well trained before entering classrooms since teachers play a pivotal role in advancing learning and licensure is a defining attribute of a high quality teacher workforce (Boe, Shin, \& Cook, 2007; ETS, 2004). In fact, it was found out that raising teaching qualification standards have made teaching more exclusive and the profession more attractive to many through an enhanced popular respect of teaching as a profession (Armstrong, 1957 as cited in Sedlak \& Schlossman, 1986).

Throughout most of the countires worldwide, teacher licensure is primarily recognized and controlled by the State. In the United States, a new legislation was enacted by Congress to oversee teacher qualification across the nation. This legislation requires colleges and state governments to report information on teacher quality, including pass rates on licensure examinations. Licensing is the legal process of permitting a person to practice a trade or profession once he or she has met certification standards (Cronin, 1983). The professional licensing of teachers in the United States dates back to the late 1600s to guarantee a minimum level of quality on behalf of the teacher. Like physicians, engineers, or attorneys, teachers are required to procure a license so that the "consumer" may somehow be assured of the quality of the "product" being provided and it also builds another criterion by which the quality of a child's education may be judged and the perceived efficacy of an educational system assured (Roth and Swail, 2000).

Similarly, the United Kingdom's teacher licensing process requires evidence of wider reading and research informed practice; it should seek to value the holistic contribution that the teacher makes to the lives of the children; it should offer an opportunity for teachers to begin to shape and monitor their own professional standards; and it should be a matter of professional pride (Kidd, 2014). Furthermore, in Australia, the teachers are considered as the greatest resource in Australian schools. Although foreign teachers are allowed to teach but they should meet the educational and professional teacher requirements, of which a licensed to teach in the country where the teacher obtained the teaching qualifications, is one of them (Education Services Australia, 2011). In like manner, the Philippines is also one of the countries that requires teachers to pass the licensure examination. The Philippine Teachers 
Professionalization Act of 1994, also known as Republic Act 7836 strengthens the regulation and supervision of the practice of teaching in the Philippines and prescribing a licensure examination for teachers and for other purposes.

The push for improved teacher quality is being driven by several studies that have shown substantial differences in student achievement across different teachers (Wright et al.,1997; Rowan et al., 2002; Rivkin et al., 2005 cited in Buddin and Zamarro, 2008). These studies reveal that licensed or certified teachers are found to produce stronger student achievement gains than do uncertified teachers (Darling-Hammond, Holtzman, Gatlin, Heilig, 2005). The findings of the study of Alexander and Fuller (2004) indicate that that certified teachers are associated with increased student achievement. Vandevoort and Berliner (2004) stressed that teachers who passed the assessments of the National Board for Professional Teaching Standards are, on average, more effective teachers in terms of academic achievement, one of the many outcomes of education for which teachers are responsible. Goldhaber and Brewer (2000) also agreed and found students taught by fully certified mathematics and science teachers had greater gains in student scores than students taught by teachers with emergency, probationary, or no certification. In addition, Goldhaber and Anthony (2007) indicate that (National Board for Professional Teaching Standards) NBPTS-certified teachers were more effective than their non-certified counterparts at increasing student achievement.

It can be surmised that passing the National Board Certification (NBC) is an effective indicator of teacher quality (Cavalluzzo, 2004). Since licensure tests are designed to set minimum teaching proficiency standards. Potential teachers who fall below the cut scores on the licensure tests might indeed have worse classroom outcomes than teachers who ultimately surpass those cut scores (Buddin and Zamaro, 2008). There is no doubt that ensuring teacher quality is the first step in achieving excellence. By understanding how teacher qualifications are most strongly related to academic success, it is imperative that educators meet all standards required for the profession through acquisition of a professional license. This aligns to Mckinsey's (2010) analysis which asserts that the quality of an education system cannot exceed the quality of its workforce which also serves as one of the most widely quoted springboards for policy reform by both policy makers and teacher organisations (Mckinsey, 2010 cited in Cordingley, 2014).

\subsection{Provisionary Eligibility}

Provisionary eligibility is a type of conditional authorization that allows a non-licensed teacher education graduates to teach in the DepEd's Senior High School program. This is granted with a condition that the teacher must pass the Licensure Examination for Teacher (LET) within 5 years after they were hired in order to obtain a permanent full time status which is in accordance to the K to 12's Implementing Rules and Regulations. In other words, instead of looking at the decreased of enrollment and shortage of qualified teachers in the transition period negatively, DepEd and HEI's are seeing it positively (Cruz, 2013) . DepEd grants provisionary eligibility to non-licensed teachers to teach in the SHS which paves the way for teachers who will lose their teaching load in College during the transition period to go to SHS. On one hand, several universities and colleges are offering SHS to accommodate 
those who will be affected. As for the displaced teachers, in light of the great need to remain employed, they will apply to become SHS teachers and accept the condition to pass the licensure examination within five years in order to have a permanent employment status; otherwise, they can opt to not take the LET and teach only on part-time basis (Official Gazette, 2013). This transition period presents a rare opportunity to upgrade our country's faculty qualifications by encouraging the non-licensed faculty to pursue the licensure examination to gain legal permission to teach in DepEd (Cruz, 2013).

In like manner, the United States also grants provisionary eligibility which is referred to as emergency certification or emergency/provisional licensing. Emergency certification is typically granted on a provisional basis, and the expectation is that the teacher will obtain the necessary credentials to become fully certified or will eventually be replaced by a regularly certified instructor (Podgursky, 2005). This is is a type of alternative certification that is used in specific and emergency situations such as teacher shortages (Alexander and Fuller, 2004). When the teacher completes the necessary requirements, the emergency notation is removed from the teacher's certificate (Roth and Swail, 2000; Paige, Rees, Petrilli, \& Gore 2004). An example is in a recent noteworthy development in Texas, due to shortage of teachers, a temporary teacher certificate was issued to allow anyone with an academic degree or advanced degree in the content area to to teach. The teacher would then be eligible for the two-year temporary teacher certificate. After two years, the teacher has to pass the Texas standard teaching certificate (Alexander and Fuller, 2004).

In addition, emergency certification is also granted to foreign-educated teachers under the state's emergency certification provisions because of critical teacher shortages. These emergency temporary certifications are usually given to prospective teachers in high-need subject areas like math, science, bilingual education, and special education. If the need is critical, some states extend temporary and emergency certifications that bypass the state licensing requirements. But such emergency teaching certification is only temporary and provisionary. The teacher still must work towards and eventually obtain an official state certification (Shannon, 2008).

Similarly, under the K-12 program, the need to recruit teachers to fill DepEd's 30,000 teaching positions for the SHS program starting SY 2016-2017 has prompted them to offer provisionary eligibility to teacher education graduates who are non-LET passers but with teaching experience. This provisionary eligibility is similar to the States of Texas and Indiana's emergency teacher certification or emergency permit (EP) option that is used in cases where a school can't find licensed teachers and has open positions that need to be filled. To work under an emergency teacher certification, an individual typically must have a bachelor's degree and expected to complete a regular teaching license within one year or it may be renewed to a maximum of two times if they wish to continue teaching in the same position (Ritz, 2011; Texas Teachers, 2015; Texas Education Agency, 2015). So, the context of this study explicates that provisionary eligibility is transitory, probationary, and provisionary. Teachers must acquire a professional license within the given timeframe in order to meet the qualification standards. 


\subsection{Temporary Eligibility}

The implementation of temporary eligibility is also one of the alternative methods to fill DepEd's need for teachers in the SHS program. This is granted to practitioners with expertise in the specialized learning areas offered by the $\mathrm{K}$ to 12 Program and graduates of technical-vocational courses with the necessary certification issued by TESDA and underwent training administered by DepEd or Higher Education Institutions (HEIs) as part-time teacher. It should be noted here that this is only temporary because they are only allowed to teach on a part-time basis because they have not met the required qualification standard under the K-12 Implimenting Rules and Regulations and the Philippine Teachers Professionalization Act of 1994.

The grant of temporary eligibility is highly selective, and recruits individuals with expertise in the specialized learning areas offered by the $\mathrm{K}$ to 12 Program, who commit to teach on part-time basis. For industry practitioners who would want to teach SHS full time, they need to take the Teaching Certification Program (TCP) or education units and pass the LET like the teachers under the Department of Education's plantilla (Official Gazette, 2013). The acquisition of a professional teaching licensed is a must, as indicated by DepEd Secreatry Armin Luistro, the practitioners, no matter how good or effective they are could not get full time positions since they don't have the teacher professional license (Malipot, 2014).

Other countries, like the United States also provide temporary eligibility to inudstry practitioners who are willing to teach in the public schools, this is called "alternative" teacher certification, which allows able individuals to teach in public schools without first passing through a college of education. The concept was to make it less cumbersome for talented individuals without teaching degrees to enter the classroom. They identify and recruit mid-career professionals with strong subject-matter knowledge to address the high retirement and high attrition rates among $\mathrm{K}-12$ teachers and a burgeoning student population (Finn and Petrilli, 2007; Paige, Rees, Petrilli, \& Gore 2004; Asmus, 2003).

Contrary to the above, industry practitioners in the Philippines are required to take Education units and pass the LET before they can be given a permanent full-time status. This conditional provision makes temporary eligibility different from the alternative certification (AC) offered in the US since the AC allows well-educated and talented individuals into public schools by hiring them as teachers straight-away, reducing or eliminating "theory" courses from their training, and using experienced teachers to mentor them during their first year or two on the job without requiring them to earn a second bachelor's degree or its equivalent. At the end, the candidate is either awarded a full certificate or sought employment elsewhere. (Finn and Petrilli, 2007; Walsh and Jacobs, 2007).

With the $\mathrm{K}$ to 12 's implementing rules and regulations, it is clearly stipulated that practitioners can be brought into the classrooms only on part-time basis. They are only granted temporary eligibility to teach because they lack the necessary qualifications to become a certified professional teacher. A permanent full time status can be granted if the practitioner has acquired a teaching certificate and has passed the Licensure Examination for Teachers (LET). What DepEd is convveying therefore is about the quality of education; 
schools must remain as does the need for bona fide, certified, and licensed teachers to address teaching aspirations and workforce quality. In the US, some states have adopted Board certification as evidence that a teacher has satisfactorily demonstrated subject mastery and thus meets the definition of a highly qualified teacher (Vandevoort and Berliner, 2004).

\section{Conclusion}

The study revealed that teacher licensure matters in the implementation of the basic education reform in the Philippine Education system. With the new Senior High School Program in placed, the Department of Education has filled up all of the senior high school classrooms with qualified teachers by streamlining hiring to ensure that only highly qualified teachers are employed to teach in this new program. Assessing teacher qualification warrants that the current education reform agenda is geared toward the attainment of quality and excellence. By understanding how teacher licensure is strongly related to teaching competitiveness and professional development, college teachers in this study believe that passing the Licensure Examination for Teachers (LET) is an important requirement before entering the classroom to certify that the teacher is highly qualified for employment. They accept, favor, and value the Department of Education's teaching licensure requirement by pursuing teacher licensure to improve the quality of teachers in the profession. The studies of Riney, Thomas, Williams, \& Kelley (2006) and Sedlak \& Schlossman (1986) relate to these findings that setting teacher licensure standards alleviate the image of the teachers and enhance respect to the teaching profession. Therefore, teacher licensure represents greater career potential because it is a hiring standard recognized by the government and public schools as an assurance of competence and quality. Although, this study limits its exploration on licensure as one of the many factors that determine teacher quality before entering the classroom; understandably, there are other areas relative to this study that are equally important to research on.

\section{References}

Aquino, A., \& Balilla, L. (2015). Pre - Service Teachers’ Licensure Examination Plans and Content Knowledge. Asia Pacific Journal of Education, Arts and Sciences, 2(2).

Alexander, C., \& Fuller, E. J. (2004). Does teacher certification matter? Teacher certification and middle school mathematics achievement in Texas. In annual meeting of the American Educational Research Association. San Diego, CA.

Asmus, E. P. (2003). Advantages and disadvantages of alternative certification. Journal of Music Teacher Education, 13(1), 5-6. http://dx.doi.org/10.1177/10570837030130010102

Boe, E. E., Shin, S., \& Cook, L. H. (2007). Does teacher preparation matter for beginning teachers in either special or general education?. The Journal of Special Education, 41(3), 158-170. https://doi.org/10.1177/00224669070410030201

Buddin, R., \& Zamarro, G. (2008). Teacher quality, teacher licensure tests, and student 
achievement. Santa Monica, CA: RAND.

Burnard, P., Gill, P., Stewart, K., Treasure, E., \& Chadwick, B. (2008). Analysing and presenting qualitative data. British Dental Journal, 204(8), 429-432. https://doi.org/10.1038/sj.bdj.2008.292

Calderon, Maria Theresa (2014). A critique of K-12 Philippine Education System. International Journal of Education and Research, 2(10).

Casiple, Rex. (2014). K-12 implementation: Its effect on teaching and non-teaching personnel in school, The Daily Guardian. Retrieved 12 August 2014 from http://thedailyguardian.net/iloilo-opinion/44169-k-12-implementation-its-effect-on-teach ing-and-non-teaching-personnel-in-school

Cavalluzzo, L. C. (2004). Is National Board Certification an Effective Signal of Teacher Quality? CNA Corporation. Retrieved November 2004 from http://www.nbpts.org/sites/default/files/documents/research/Cavalluzzo_IsNBCAnEffect iveSignalofTeachingQuality.pdf

Chan, Joselito G., \& Robles, Reynaldo B. (1994). Republic Act 7836, Philippine Teachers Professionalization Act of 1994. Retrieved 16 December 1994 from http://www.chanrobles.com/republicactno7836.htm\#.WBHZei196Hs

Cohen, Deborah J., \& Benjamin F. Crabtree. E. (2008). valuative criteria for qualitative research in health care: controversies and recommendations. The Annals of Family Medicine, 6(4), 331-339. http://dx.doi.org/10.1370/afm.818.

Commission on Higher Education (2015). CHED K TO 12 Transition Program: Investing in the Future of Philippine Higher Education. Retrieved from https://chedk12.wordpress.com/transition-in-higher-education/

Cordingley, Philippa. (2014). Teacher licensing and collaboration: a model for developing the confidence of the profession as a whole. Licensed to Create. RSA Action and Research Center. London, UK.

Creswell, John. (1998). Qualitative inquiry and research design: Choosing among five traditions (p.64). Thousand Oaks, Sage. CA, USA.

Creswell, J. W., \& Plano Clark, V.L. (2006). Designing and Conducting Mixed Methods Research (2nd Edition). Sage Publications Inc. Thousand Oaks, CA.

Creswell, J. W. (2013). Research design: Qualitative, quantitative, and mixed methods approaches. Sage publications. USA.

Cronin, J. (1983). State regulation of teacher preparation. In Shulman \& Sykes (Eds.), Handbook of teaching and policy. New York: Longman, Inc.

Cruz, Isagani (2013). College teachers in 2016. The Philippine Star. Retrieved 17 May 2013 from

http://www.philstar.com/education-and-home/2013/03/07/916710/college-teachers-2016 
Darling-Hammond, L., Holtzman, D. J., Gatlin, S. J., \& Heilig, J. V. (2005). Does Teacher Preparation Matter? Evidence about Teacher Certification, Teach for America, and Teacher Effectiveness. Education policy analysis archives, 13(42), n42. https://doi.org/10.14507/epaa.v13n42.2005

Education Services Australia (2011). Australian Professional Standards for Teachers. $\begin{array}{llll}\text { Retrieved } \quad \text { February } & 2011 & \text { from }\end{array}$ http://www.aitsl.edu.au/docs/default-source/apst-resources/australian_professional_stand ard_for_teachers_final.pdf

Finn, Chester E. Jr., \& Petrilli, Michael J. (2007). Alternative Certification Isn't Alternative. Thomas B. Fordham Institute.

Geronimo, Jee (2014). College professors fear massive retrenchment due to $\mathrm{K}$ to 12 . $\begin{array}{lllll}\text { Retrieved } & 12 & \text { June } & 2014 & \text { from }\end{array}$ http://www.rappler.com/nation/60428-college-professors-fear-massive-retrenchment-k12

Gill, P., Stewart, K., Treasure, E., \& Chadwick, B. (2008). Methods of data collection in qualitative research: interviews and focus groups. British dental journal, 204(6), 291-295. http://dx.doi.org/10.1038/bdj.2008.192

Goldhaber, D. D., \& Brewer, D. J. (2000). Does teacher certification matter? High school teacher certification status and student achievement. Education Evaluation and Policy Analysis, 22, 129-45. https://doi.org/10.3102/01623737022002129

Goldhaber, D., \& Anthony, E. (2007). Can teacher quality be effectively assessed? National board certification as a signal of effective teaching. The Review of Economics and Statistics, 89(1), 134-150. https://doi.org/10.1162/rest.89.1.134

Groenewald, Thomas. (2004). A phenomenological research design illustrated. International Journal of Qualitative Methods, 3(1), 42-55.

Guetterman, T. C. (2015). Descriptions of sampling practices within five approaches to qualitative research in education and the health sciences. In Forum Qualitative Sozialforschung/Forum: Qualitative Social Research, 16(2).

Hardon, Anita, Hodgkin, Catherine \& Fresle, Daphne (2004). How to Investigate the Use of Medicines by Consumers. World Health Organization and University of Amsterdam. Switzerland

Holroyd, C. (2001). Phenomenological research method, design and procedure: A phenomenological investigation of the phenomenon of being-in-community as experienced by two individuals who have participated in a community building workshop. Indo-Pacific Journal of Phenomenology, 1(1), 1-10. http://dx.doi.org/10.1080/20797222.2001.11433859

Ivankova, N.V., \& Stick, S.L. (2007). Students’ persistence in a distributed doctoral program in educational leadership in higher education: A mixed methods study. Research in Higher Education, 48(1), 93-135. http://dx.doi.org/10.1007/s11162-006-9025-4 
Kent, Jason (2015). The Power of PE License. Retrieved from https://www.monster.com/career-advice/article/professional-engineer-license-pe

Kidd, Debra (2014). Licensed to matter. Licensed to Create. RSA Action and Research Center.
London,
$U K$.
Retrieved
from

http://www.dylanwiliam.org/Dylan_Wiliams_website/DW_publications_files/Licensed

\%20to\%20create\%20-\%20Ten\%20essays\%20on\%20improving\%20teacher\%20quality

\%20(RSA\%202014).pdf

Lacamiento, Grace Melanie I. (2014). K to 12: The effect on teachers. The Freeman.

$\begin{array}{llll}\text { Retrieved } 27 & \text { July } & 2014 & \text { from }\end{array}$

http://www.philstar.com/cebu-news/2014/06/27/1339633/k-12-effect-teachers

Lacey, A., \& Luff, D. (2001). Qualitative data analysis (pp. 320-357). Sheffield: Trent focus. Retrieved from https://www.rds-yh.nihr.ac.uk/wp-content/uploads/2013/05/9_Qualitative_Data_Analysi s_Revision_2009.pdf

Leech, N. L., \& Onwuegbuzie, A. J. (2007). An array of qualitative data analysis tools: A call for data analysis triangulation. School psychology quarterly, 22(4), 557. https://doi.org/10.1037/1045-3830.22.4.557

Lester, Stan. (1999). An introduction to phenomenological research. Taunton UK, Stan Lester Developments.

Retrieved

from https://www.researchgate.net/profile/Stan_Lester/publication/255647619_An_introducti on_to_phenomenological_research/links/545a05e30cf2cf5164840df6.pdf

Malipot, Ina H. (2014). K to 12 threatens jobs of 85,000 college workers, Manila Bulletin. $\begin{array}{lllll}\text { Retrieved } & 27 & \text { June } & 2014 & \text { from }\end{array}$ https://disqus.com/home/discussion/manilabulletindotcomdotph/k_to_12_threatens_jobs _of_85000_college_workers/

Mason, Mark (2010). Sample Size and Saturation in PhD Studies Using Qualitative Interviews. Forum Qualitative Sozialforschung/Forum: Qualitative Social Research, 11(3), Art. 8.

Morse, Janice M. (1994). Designing funded qualitative research. In Norman K. Denzin \& Yvonna S. Lincoln (Eds.), Handbook of qualitative research (2nd ed.), pp.220-35. Thousand Oaks, CA: Sage.

National Board for Professional Teaching Standards (2015). About Certification, Elevating Teaching, Empowering Teachers. Retrieved 2015 December 5 from http://www.boardcertifiedteachers.org/about-certification

Official Gazette (2013). Implementing Rules and Regulations of the Enhanced Basic Education Act of 2013. Retrieved 4 September 2013 from http://www.gov.ph/2013/09/04/irr-republic-act-no-10533/

Official Gazette (2013). Republic Act 10533. Retrieved 15 May 2013 from 
http://www.gov.ph/2013/05/15/republic-act-no-10533/

Paige, Rod, Rees, Nina, Petrilli, Michael, Gore, Patricia (2004). Alternative Routes to Teacher Certification. US Department of Education. Retrieved from https://www2.ed.gov/admins/tchrqual/recruit/altroutes/report.pdf

Podgursky, M. (2005). Teacher licensing in US public schools: The case for simplicity and flexibility. Peabody Journal of Education, 80(3), 15-43. https://doi.org/10.1207/s15327930pje8003_3

Professional Teaching Certification Advice (2014). Benefits of Teaching Certification. $\begin{array}{lllll}\text { Retrieved } & 5 & \text { May } & 2014 & \text { from }\end{array}$ http://www.teachingcertificationhelp.com/benefits-of-teaching-certification.html

Riney, M. R., Thomas, C., Williams, G., \& Kelley, B. (2006). National Implications: Teacher Education Students' Perceptions of State Licensure Requirements and Pedagogical Training. National Forum of Teacher Education Journal, 16(3), 1-7.

Roth, D., \& Swail, W. S. (2000). Certification and Teacher Preparation in the United States. Pacific Resources for Education and Learning. Los Angeles: CA.

Sedlak, M., \& Schlossman, S. (1986). Who will teach? Historical perspectives on the changing appeal of teaching as a profession. Publication Sales, The Rand Corporation, 1700 Main Street, PO Box 2138, Santa Monica, CA 90406-2138.

Shannon, E. (2008). Teacher certification for foreign-educated teachers. Retrieved 26 March 2008 from http://learn.latpro.com/teacher-certification-for-foreign-educated-teachers/

ETS (2004). Where Do We Stand on Teacher Quality. An Issue Paper from ETS, Princeton, New Jersey. Retrieved from https://www.ets.org/Media/Education_Topics/pdf/teacherquality.pdf

Sutton, J., \& Austin, Z. (2015). Qualitative Research: Data Collection, Analysis, and Management. The Canadian Journal of Hospital Pharmacy, 68(3), 226-231. http://dx.doi.org/10.4212/cjhp.v68i3.1456

Texas Education Agency (2015). Becoming a Certified Texas Educator through an Alternative Certification Program. Retrieved 12 February 2015 from http://tea.texas.gov/index2.aspx?id=7073

Texas Teachers (2015). Texas Teachers Alternative Certification. Retrieved 12 February 2015 from http://www.texasteachers.org/how-it-works/

Vandevoort, L. G., \& Berliner, D. C. (2004). National Board Certified Teachers and Their Students' Achievement. Education policy analysis archives, 12(46), n46. http://dx.doi.org/10.14507/epaa.v12n46.2004

Walsh, K., \& Jacobs, S. (2007). Alternative Certification Isn't Alternative. Thomas B. Fordham Institute. 


\section{Copyright Disclaimer}

Copyright for this article is retained by the author(s), with first publication rights granted to the journal.

This is an open-access article distributed under the terms and conditions of the Creative Commons Attribution license (http://creativecommons.org/licenses/by/3.0/). 